\title{
Storage Stability of Functional Kadaknath Chicken Patties under Vacuum Packaging
}

\author{
Sunil Badole ${ }^{1}$, N.K Nayak ${ }^{1}$, M.K. Mehta ${ }^{2}$ and Ranjeet Aich $^{2,3}$ \\ ${ }^{1}$ Department of Livestock Products Technology, ${ }^{2}$ Department of Animal Nutrition, \\ ${ }^{3}$ Department of Veterinary Microbiology, College of Veterinary Science \& A.H., Mhow, \\ Indore (453446), M.P., India \\ *Corresponding author
}

\section{Keywords}

Kadaknath storage study, Functional patties, Sensory attributes

\section{Article Info}

Accepted:

30 October 2019

Available Online:

10 November 2019
Fiber enriched low fat functional kadaknath chicken patties were developed and packaged in vacuum condition and evaluated for storage stability under refrigeration. The $\mathrm{pH}$, TBA and FFA values of fibre enriched low fat kadaknath chicken patties were lower as compared to control throughout the storage. A progressive and significant $(\mathrm{P}<0.05)$ increment in the $\mathrm{pH}$, TBA and FFA values of control as well as fiber enriched low fat kadaknath chicken patties were observed with the advancement of storage. The total plate count (TPC) followed a significantly $(\mathrm{P}<0.05)$ increasing pattern from 0 to 28 day in control as well as fiber enriched low fat kadaknath chicken patties. Psychrotropic counts under vacuum packaging were detected from $14^{\text {th }}$ day of storage and Yeast and Mold were not detected during the entire period of storage. Coliform were also not detected during the entire period of storage. Sensory attributes under storage study did not have any significant $(\mathrm{P}>0.05)$ difference between control and fiber enriched low fat kadaknath chicken patties on all storage days. The mean scores for all the sensory attributes for both control as well as fiber enriched low fat kadaknath chicken patties decreased gradually with increasing storage period. From the study it was concluded that the fiber enriched low fat kadaknath chicken patties may be considered as health full product which was very well stable and accepted for a period of 28 days in vacuum packaging under refrigeration.

\section{Introduction}

Kadaknath is only black meat chicken (B.M.C.) breed of India. It is a native bird of Madhya Pradesh, reared mainly by the tribal communities of Jhabua which is adjacent to Indore (Malwa region). The bird is very popular locally mainly due to its adaptability to the local environment, disease resistance, tasty meat quality, texture and flavor. Growing understanding of the relationship between diet and health is leading to new insights into the effect of food ingredients on physiological function and health, inducing increased 
consumer demand for healthy, nutritious foods with additional health promoting functions. Most research into meat-based functional foods has been confined to animal production or technological strategies for increasing the presence of healthy compounds (1-3). A diet high in fiber usually advocates a healthier lifestyle and fiber intake can be viewed as a marker of healthy diet (4). Lipid oxidation is of great concern to the consumer because it causes physical and chemical deterioration of food quality, such as undesirable changes in taste, texture, appearance and development of rancidity, losses of important nutritional values and formation of potentially harmful components including free radicals and reactive aldehydes (5).

Hence, there is a need for using suitable ingredients with good shelf-life which is able to replace fat and used as source of fiber without affecting quality. Generally, low-fat meat and chicken products have generated a variety of strategies for reducing fat and increasing fiber, but the final goal has to develop low fat fiber enriched with retaining traditional full-fat flavor, taste and texture. So, by taking all these considerations, the present study was aimed to assess the storage stability of vacuum packed fiber enriched low fat kadaknath chicken patties under refrigeration..

\section{Materials and Methods}

\section{Meat and additives}

Kadaknath chicken of 4-5 months age were be procured from Department of Poultry Science of the college, slaughtered according to traditional halal method. The meat was, packed in low-density polyethylene (LDPE) bags and brought to the laboratory within 20 min. The meat was deboned, trimmed-off separable fat and connective tissue. The samples were kept for conditioning in a refrigerator at $4 \pm 1{ }^{\circ} \mathrm{C}$ for $6-8 \mathrm{~h}$ and then frozen at $-18^{\circ} \mathrm{C}$ till further use. The samples were used after partial thawing for $15 \mathrm{~h}$ at $4^{\circ} \mathrm{C}$. Various Flours, condiments (onion, ginger, and garlic), oil, salt, gram hulls were purchased from standard shop of local market. The composition of spice mix is given in Table 1. The ingredients in desired ratio were procured from local market, dried at $45 \pm 2{ }^{\circ} \mathrm{C}$ for 2 hours followed by grinding and sieving through 100 mesh. The spice mix was stored in low density polyethylene bags and used as per requirement. All the chemicals and media used in the study were of analytical grade and obtained from standard firm.

\section{Processing}

The common salt, vegetable oil, refined wheat flour (maida), sodium tripolyphosphate, spice mixture and condiment mix were added to weighed meat according to formulation. Meat emulsion for patties was prepared in Bowl Chopper (MOD C 15 2.8G 4.0 HP, Marsango, Italy). Minced meat was blended with salt and sodium tripolyphosphate for 1.5 minute. Adequate care was taken to keep the end point temperature below $18^{\circ} \mathrm{C}$ by preparing the emulsion in cool hours of morning, by addition of meat and other ingredients in chilled/partially thawed form and by addition of crushed ice or ice water. The emulsion were prepared in two different groups as per given formulation (Table 2).

Kadaknath Chicken meat was partially thawed overnight, cut into small cubes and double minced in an electrolux mincer. Meat emulsion was prepared in a bowl chopper (Seydelmann K20, Ras, Germany). Preweighed quantity of minced chicken meat, salt, sodium tripolyphosphate were added and chopped for about 2-3 minutes. It was again chopped for 2 minutes after the addition of ice flakes. Refined vegetable oil was slowly incorporated while chopping till it was completely dispersed in the batter. 
Condiments paste, dry spices mix and refined flour were added. Chopping was continued till uniform dispersion of all the ingredients and desired consistency of the emulsion was achieved. Weighed quantity of emulsion was taken and molded in to patties shape. Then patties were cooked in hot air oven at $180^{\circ} \mathrm{c}$ for 12 minutes and 4 minutes after turning. Patties were cooled at room temperature and vacuum packed in low-density polyethylene pouches and stored under refrigerated $\left(4 \pm 1^{\circ} \mathrm{C}\right)$.

\section{Packaging materials}

Low density Polyethylene (LDPE) bags of 250 gauge thickness were sourced from local market for packaging and were pre-sterilized by exposing to U.V. light for 30 minutes before use.

\section{Physicochemical analysis}

Prior to measurement, $\mathrm{pH}$ meter was calibrated every time as per the manufacturer's instructions using known buffers of $\mathrm{pH} 7.0$ and 4.01. Reading was taken twice for each sample and average of reading was taken as $\mathrm{pH}$ of sample. TBA value was estimated as per procedure given (5). Free fatty acid value was determined by the prescribed method (6)

Microbiological analysis: (Total Plate Count, Psychrotropic count, Coliform count and Yeast \& Mould Count): Samples was prepared and analyzed (7).

\section{Sensory evaluation}

An experienced sensory panel consisting of seven scientists and post-graduate students of the university evaluated the sensory characteristics of the warmed product viz., appearance, flavour, juiciness, texture, mouth coating and overall acceptability using 8-point objective scale where 8 denoted extremely desirable and 1 denoted extremely undesirable (8).

\section{Statistical analysis}

The data obtained in the study on various parameters were statistically analyzed on 'SPSS16.0 ' software package as per standard method. Data were subjected to one way analysis of variance, homogeneity test and Duncan's Multiple Range Test (DMRT) for comparing the means to find the effects between samples (9).

\section{Results and Discussion}

The shelf life of control as well as fiber enriched kadaknath chicken patties was assessed under vacuum packaging. The patties were packaged in LDPE pouches under vacuum packaged and stored at refrigeration temperature $\left(4 \pm 1^{\circ} \mathrm{C}\right)$ and were assessed for different physicochemical, microbiological and sensory attributes at regular interval (Day $0,7,14,21$, and 28) till incipient spoilage was evident.

\section{Physico- chemical parameters}

The mean $\mathrm{pH}$, TBA, and FFA values for control and fiber enrich low fat kadaknath chicken patties during storage at 7 days of regular interval are presented in Table 3.

The $\mathrm{pH}$, TBA and FFA value were differed significantly $(\mathrm{P}<0.05)$ during storage for control as well as treatment. The $\mathrm{pH}$ of fiber enriched low fat kadaknath chicken patties was not differ significantly $(\mathrm{P}>0.05)$ from control throughout storage.

\section{Microbiological analysis}

The mean value of Total plate count, Psychotropic count, Coliform count and Yeast $\&$ Mold count for control and fiber enriched 
and low fat vacuum packaged kadaknath chicken patties during storage of 28 days of at 7 days of regular interval are presented in Table 4. The data presented in the table differ significantly $(\mathrm{P}<0.05)$ with advancement of storage period in control as well treatment.

\section{Sensory evaluation}

The mean general appearance, flavor, texture, juiciness, mouth coating, saltiness and overall acceptability for control and fiber enriched low fat vacuum packaged kadaknath patties during storage at 7 days of regular interval till insipient storage interval of vacuum packaged were presented in Table 5. The data presented in the table for general appearance, flavor, texture, juiciness and overall acceptability indicated significantly $(\mathrm{P}<0.05)$ difference during the storage.

\section{Physico- chemical parameters}

The $\mathrm{pH}$ value of control as well as fiber enriched low fat kadaknath chicken patties increased significantly $(\mathrm{P}<0.05)$ with the advancement of storage period. However, developed kadaknath chicken patties showed no significant $(\mathrm{P}>0.05)$ difference between 0 and 7 days of storage. Thereafter, increased gradually and showed significantly $(\mathrm{P}<0.05)$ difference on $14^{\text {th }}$ day. However, on $28^{\text {th }}$ day of storage a slight difference was noticed.

Such pattern in $\mathrm{pH}$ might be due to the combine action of psychrotrophic bacteria which ferment carbohydrate present in the ingredients used in the formulation of the product. The subsequent increment in the $\mathrm{pH}$ value was due to the liberation of metabolites from the bacterial activities as the microbial load enhance with the storage period. In guinea fowl sausage (10) and in restructured chicken chunk (11) also observed increasing pattern in $\mathrm{pH}$ under vacuum packaged at refrigeration temperature.
The TBA value for control product was nonsignificantly $(\mathrm{P}>0.05)$ lower as compared to fiber enriched low fat kadaknath chicken patties throughout the entire storage. A progressive and significant $\quad(\mathrm{P}<0.05)$ increment in the TBA values of control as well as fiber enriched low fat kadaknath chicken patties were observed with the advancement of storage. This could be due to increased lipid oxidation and production of volatile metabolites in the presence of oxygen during aerobic storage. Other worker also reported progressive increase in lipid oxidation during storage period. It might to be due to vacuum packaged meat was more resistant to lipid oxidation than aerobically packaged meat because the availability of oxygen is more important for the lipid oxidation (12). Similar trends in TBA value was noticed in vacuum packaged meat patties and ready to eat Vawksa rep (13-14).

FFA values of fiber enriched low fat kadaknath chicken patties were observed lower compared to control on each day of storage. However, with the advancement of storage period the FFA value showed linear significantly $(\mathrm{P}<0.05)$ increasing trend from 0 to 28 day of refrigeration storage. An increasing FFA value with the advancement of storage period in chicken nuggets under refrigeration was also recorded (15). Similar pattern of increasing FFA content with the advancement of storage in vacuum packaged meat sausage in vacuum packaged restructured chicken steaks also reported (10\&16).

\section{Microbiological}

The total plate count (TPC) followed a significantly $(\mathrm{P}<0.05)$ increasing pattern from 0 to 28 day in control as well as fiber enriched low fat kadaknath chicken patties. However, TPC did not differ significantly $(\mathrm{P}>0.05)$ between control and treatment with the 
progress of storage period. But remain higher in treatment compared to control throughout the storage. It could be due to incorporation of black gram hull in kadaknath chicken patties which could have provided easy carbohydrate substrate for microbial growth increasing trend with the advancement of storage period was also reported in buffalo tripe rolls at refrigerated storage under vacuum condition (17).

Psychrotrophic counts were not detected up to 7 day of storage either in control and/or fiber enriched low fat kadaknath chicken patties. This could be due to destruction of psychrotrops during cooking. These counts were detected on 14 day of storage in both control and fiber enriched low fat kadaknath chicken patties. This might be due to recovery of injured organism and then multiplication during subsequent period of storage. The count remained within the permissible limit of $\log 4.6 \mathrm{CFU} / \mathrm{gm}$ as reported in cooked meat products (18). Our findings were supported by the observation taken buffalo tripe rolls at refrigerated storage under vacuum condition (17).

Coliform were not detected during the entire period of storage in both control as well as fiber enriched low fat kadaknath chicken patties. The absence of coliform is due to their destruction during cooking above their death point of $57^{0} \mathrm{C}$. Further hygienic practices followed during and after preparation of product. Similar results of zero count of Coliform were also reported by in low fat vacuum packaged restructured chicken block; in buffalo meat keema and in chicken patties respectively (19-21).

Yeast and Mold count was not detected during the entire period of storage in both control as well as fiber enriched low fat kadaknath chicken patties. This might be due to absence of favorable condition (like humid climate for the growth of yeast and mold during the experiment). Similar results were found in vacuum packaged buffalo meat rolls (22).

\section{Sensory evaluation}

The score for general appearance did not have significant $\quad(\mathrm{P}>0.05)$ difference between control and fiber enriched low fat kadaknath chicken patties on all storage days. The mean score for general appearance of both control and fiber enriched low fat kadaknath chicken patties decreased gradually with increasing in storage period. Similar results were reported in vacuum packaged guinea fowl sausages and in refrigerated chicken patties (15\&23).

Mean flavor score between control and fiber enriched low fat kadaknath chicken patties did not differ significantly $(\mathrm{P}>0.05)$ throughout the storage. However, on subsequent storage significant $(\mathrm{P}<0.05)$ difference was noticed from $21^{\text {th }}$ day onwards. The pattern was similar for control as well as fiber enriched low fat kadaknath chicken patties. The progressive decrease in flavor could be correlated to some increase in TBA value of meat product (5). The decrease in flavor score was also reported in vacuum packaged chevon sausages (24).

No significant $(\mathrm{P}>0.05)$ difference in the score of texture between control and fiber enriched low fat kadaknath chicken patties was recorded during the storage. Further, with the advancement of storage period from $14^{\text {th }}$ day, the scores were decreased significantly $(\mathrm{P}<0.05)$. The decreasing trend in texture score during storage under refrigeration in meat products were also reported in chicken patties and in vacuum packaged restructured chicken steak (14 \& 25). 
Table.1 Composition of spice mix

\begin{tabular}{|l|c|c|}
\hline S. No. & Name of ingredients & Percentage of mix. $\mathbf{~ w / w ) ~}$ \\
\hline $\mathbf{1 .}$ & Anise & 10 \\
\hline $\mathbf{2 .}$ & Black pepper & 5 \\
\hline $\mathbf{3 .}$ & Capsicum & 10 \\
\hline $\mathbf{4 .}$ & Caraway & 10 \\
\hline $\mathbf{5 .}$ & Cardamom & 4 \\
\hline $\mathbf{6 .}$ & Cloves & 2 \\
\hline $\mathbf{7 .}$ & Cinnamon & 4 \\
\hline $\mathbf{8 .}$ & Cumin & 20 \\
\hline $\mathbf{9 .}$ & Dry ginger & 10 \\
\hline $\mathbf{1 0 .}$ & Turmeric & 10 \\
\hline $\mathbf{1 1}$ & Coriander & 15 \\
\hline
\end{tabular}

Table.2 Formulation for control and functional (fiber enriched-low fat kadaknath) chicken patties

\begin{tabular}{|l|c|c|c|}
\hline S.No. & Ingredients & Control & Functional \\
\hline 1. & Meat (\%) & 75.0 & 69.0 \\
\hline 2. & Gram Hull (\%) & 00 & 6.0 \\
\hline 3. & Guargum & 00 & 1.0 \\
\hline $\mathbf{4 .}$ & Refined Flour (\%) & 4.0 & 4.0 \\
\hline $\mathbf{5 .}$ & Vegetable oil (\%) & 6.0 & 3.0 \\
\hline $\mathbf{6 .}$ & Condiments (\%) & 3.8 & 3.8 \\
\hline $\mathbf{7 .}$ & Ice - Flakes (\%) & 7.0 & 9.0 \\
\hline $\mathbf{8 .}$ & Spices (\%) & 2.0 & 2.0 \\
\hline $\mathbf{9 .}$ & Salt (\%) & 1.8 & 1.8 \\
\hline $\mathbf{1 0 .}$ & STPP (\%) & 0.4 & 0.4 \\
\hline $\mathbf{1 1 .}$ & Total (\%) & 100 & 100 \\
\hline
\end{tabular}

Table.3 Effect of vacuum packaging on $\mathrm{pH}$, TBA and FFA values (Mean \pm SE) of fiber enriched low fat kadaknath chicken patties stored at $4 \pm 1^{\circ} \mathrm{C}$

\begin{tabular}{|c|c|c|c|c|c|}
\hline \multirow[b]{2}{*}{ Treatment } & \multicolumn{5}{|c|}{ Storage days } \\
\hline & 0 & 7 & 14 & 21 & 28 \\
\hline \multicolumn{6}{|c|}{ PH } \\
\hline Control & $6.22 \pm 0.05^{\mathrm{a}}$ & $6.31 \pm 0.03^{\mathrm{ab}}$ & $6.34 \pm 0.04^{b}$ & $6.40 \pm 0.03^{b}$ & $6.42 \pm 0.03^{b}$ \\
\hline Treatment & $6.26 \pm 0.04^{\mathrm{a}}$ & $6.29 \pm 0.03^{\mathrm{a}}$ & $6.35 \pm 0.02^{\mathrm{ab}}$ & $6.41 \pm 0.02^{b}$ & $6.40 \pm 0.02^{b}$ \\
\hline \multicolumn{6}{|c|}{ TBA (mg malonaldehyde/kg) } \\
\hline Control & $0.461 \pm 0.027^{\mathrm{a}}$ & $0.463 \pm 0.033^{\mathrm{a}}$ & $0.505 \pm 0.029^{\mathrm{a}}$ & $0.695 \pm 0.027^{b}$ & $0.962 \pm 0.020^{c}$ \\
\hline Treatment & $0.417 \pm 0.031^{\mathrm{a}}$ & $0.461 \pm 0.019^{\mathrm{a}}$ & $0.512 \pm 0.027^{\mathrm{a}}$ & $0.655 \pm 0.029^{b}$ & $0.919 \pm 0.031^{c}$ \\
\hline \multicolumn{6}{|c|}{ FFA (\% oleic acid) } \\
\hline Control & $0.212 \pm 0.003^{\mathrm{a}}$ & $0.442 \pm 0.004^{b}$ & $0.724 \pm 0.003^{c}$ & $0.826 \pm 0.004^{d}$ & $0.873 \pm 0.004^{\mathrm{d}}$ \\
\hline Treatment & $0.200 \pm 0.059^{\mathrm{a}}$ & $0.376 \pm 0.015^{b}$ & $0.703 \pm 0.005^{\mathrm{c}}$ & $0.793 \pm 0.004^{\mathrm{cd}}$ & $0.865 \pm 0.006^{\mathrm{d}}$ \\
\hline
\end{tabular}

Means bearing different superscripts $(a, b, c, d \ldots)$ in a row differ significantly $(\mathrm{P}<0.05)$. 
Table.4 Effect of vacuum packaging on microbial count (Mean \pm SE) of fiber enriched low fat kadaknath chicken patties stored at $4 \pm 1^{\circ} \mathrm{C}$

\begin{tabular}{|c|c|c|c|c|c|}
\hline \multirow{2}{*}{ Treatment } & \multicolumn{5}{|c|}{ storage days } \\
\cline { 2 - 6 } & 0 & 7 & 14 & 21 & 28 \\
\hline \multirow{5}{*}{ Control } & $2.68 \pm 0.08^{\mathrm{a}}$ & $2.75 \pm 0.10^{\mathrm{a}}$ & $3.08 \pm 0.06^{\mathrm{ab}}$ & $3.36 \pm 0.12^{\mathrm{b}}$ & $3.69 \pm 0.09^{\mathrm{c}}$ \\
\hline Treatment & $2.62 \pm 0.12^{\mathrm{a}}$ & $2.91 \pm 0.16^{\mathrm{a}}$ & $3.06 \pm 0.11^{\mathrm{ab}}$ & $3.37 \pm 0.09^{\mathrm{b}}$ & $3.71 \pm 0.14^{\mathrm{c}}$ \\
\hline \multicolumn{7}{|c|}{ Psychotropic count (cfu/gm) } \\
\hline Control & ND & ND & $0.42 \pm 0.18$ & $0.86 \pm 0.16$ & $1.24 \pm 0.12$ \\
\hline Treatment & ND d & ND & $0.51 \pm 0.12$ & $0.96 \pm 0.13$ & $1.23 \pm 0.14$ \\
\hline \multicolumn{7}{|c|}{ Coliform count (cfu/gm) } \\
\hline Control & ND & ND & ND & ND & ND \\
\hline Treatment & ND & ND & ND & ND & ND \\
\hline Control & ND & Yeast \& mold (cfu/gm) \\
\hline Treatment & ND & ND & ND & ND & ND \\
\hline
\end{tabular}

* ND= Not Detected

Means bearing different superscripts $(a, b, c, d \ldots)$ in a row differ significantly $(\mathrm{P}<0.05)$.

Table.5 Effect of vacuum packaging on sensory attributes (Mean \pm SE) of fiber enriched low fat kadaknath chicken patties stored at $4 \pm 1^{\circ} \mathrm{C}$

\begin{tabular}{|c|c|c|c|c|c|}
\hline \multirow[t]{2}{*}{ Treatment } & \multicolumn{5}{|c|}{ Storage days } \\
\hline & 0 & 7 & 14 & 21 & 28 \\
\hline \multicolumn{6}{|c|}{ General appearance } \\
\hline Control & $7.47 \pm 0.12^{\mathrm{c}}$ & $7.14 \pm 0.14^{\mathrm{bc}}$ & $6.57 \pm 0.12^{\mathrm{bc}}$ & $6.14 \pm 0.18^{b}$ & $5.61 \pm 0.15^{\mathrm{a}}$ \\
\hline Treatment & $7.47 \pm 0.14^{\mathrm{c}}$ & $7.14 \pm 0.13^{\mathrm{bc}}$ & $6.61 \pm 0.16^{\mathrm{bc}}$ & $6.14 \pm 0.11^{b}$ & $5.61 \pm 0.10^{\mathrm{a}}$ \\
\hline \multicolumn{6}{|c|}{ Flavor } \\
\hline Control & $7.33 \pm 021^{\mathrm{c}}$ & $7.02 \pm 0.14^{\mathrm{bc}}$ & $6.80 \pm 0.12^{\mathrm{bc}}$ & $6.38 \pm 0.11^{b}$ & $5.97 \pm 0.18^{\mathrm{a}}$ \\
\hline Treatment & $7.38 \pm 0.18^{c}$ & $7.04 \pm 0.21^{\mathrm{bc}}$ & $6.85 \pm 0.16^{\mathrm{bc}}$ & $6.42 \pm 0.14^{b}$ & $5.97 \pm 0.13^{\mathrm{a}}$ \\
\hline \multicolumn{6}{|c|}{ Texture } \\
\hline Control & $7.09 \pm 0.14^{c}$ & $6.95 \pm 0.21^{\mathrm{c}}$ & $6.71 \pm 0.20^{c}$ & $6.09 \pm 0.16^{b}$ & $5.52 \pm 0.12^{\mathrm{a}}$ \\
\hline Treatment & $7.04 \pm 0.14^{\mathrm{c}}$ & $6.95 \pm 0.15^{\mathrm{c}}$ & $6.71 \pm 0.16^{\mathrm{c}}$ & $6.28 \pm 0.21^{b}$ & $5.66 \pm 0.11^{\mathrm{a}}$ \\
\hline \multicolumn{6}{|c|}{ Saltiness } \\
\hline Control & $7.04 \pm 0.14$ & $6.95 \pm 0.15$ & $6.95 \pm 0.21$ & $6.85 \pm 0.23$ & $6.80 \pm 0.24$ \\
\hline Treatment & $7.09 \pm 0.16$ & $6.90 \pm 0.18$ & $6.95 \pm 0.21$ & $6.90 \pm 0.22$ & $6.76 \pm 0.25$ \\
\hline \multicolumn{6}{|c|}{ Juiciness } \\
\hline Control & $7.09 \pm 0.12^{b}$ & $6.76 \pm 0.16^{b}$ & $6.57 \pm 0.09^{b}$ & $6.09 \pm 0.13^{\mathrm{a}}$ & $5.85 \pm 0.08^{\mathrm{a}}$ \\
\hline Treatment & $7.19 \pm 0.21^{b}$ & $6.80 \pm 0.18^{b}$ & $6.61 \pm 0.08^{b}$ & $5.95 \pm 0.10^{\mathrm{a}}$ & $5.90 \pm 0.14^{\mathrm{a}}$ \\
\hline \multicolumn{6}{|c|}{ Mouth coating } \\
\hline Control & $6.73 \pm 0.11^{b}$ & $6.66 \pm 0.12^{b}$ & $6.38 \pm 0.14^{b}$ & $6.14 \pm 0.17^{\mathrm{ab}}$ & $5.76 \pm 0.16^{\mathrm{a}}$ \\
\hline Treatment & $6.04 \pm 0.18^{b}$ & $6.71 \pm 0.14^{b}$ & $6.42 \pm 0.21^{\mathrm{b}}$ & $6.19 \pm 0.18^{\mathrm{ab}}$ & $5.80 \pm 0.12 \mathrm{a}$ \\
\hline \multicolumn{6}{|c|}{ Overall acceptability } \\
\hline Control & $7.14 \pm 0.24^{c}$ & $7.02 \pm 0.20^{c}$ & $6.85 \pm 0.12^{b c}$ & $6.66 \pm 0.12^{b}$ & $6.14 \pm 0.13^{\mathrm{a}}$ \\
\hline Treatment & $7.19 \pm 0.14^{c}$ & $7.09 \pm 0.12^{c}$ & $6.80 \pm 0.11^{b c}$ & $6.66 \pm 0.16^{b}$ & $6.09 \pm 0.12^{\mathrm{a}}$ \\
\hline
\end{tabular}

Means bearing different superscripts $(a, b, c, d \ldots)$ in a row differ significantly $(\mathrm{P}<0.05)$. 
The score for saltiness did not have significant $(\mathrm{P}>0.05)$ difference between control and fiber enriched low fat kadaknath chicken patties on all storage days. Subsequently with the advancement in storage period no significant $(\mathrm{P}>0.05)$ difference was recorded in either of the product throughout the storage period.

No significant $(\mathrm{P}>0.05)$ difference in the score of juiciness between control and fiber enriched low fat kadaknath chicken patties was recorded during the storage.

The score presented in table showed linear decreasing trend from 0 to 28 day under refrigeration in fiber enriched low fat kadaknath chicken patties as well as in control. A significant $(\mathrm{P}<0.05)$ difference was noticed from $21^{\text {th }}$ day in either of the product. The decreasing value of juiciness with the advancement of storage in different chicken meat products were also reported (26-27).

No significant $(\mathrm{P}>0.05)$ difference in the score of mouth coating between control and fiber enriched low fat kadaknath chicken patties was recorded during the storage. Further, with the advancement of the storage from $14^{\text {th }}$ day a significant $(\mathrm{P}<0.05)$ difference was observed in both control as well as fiber enriched low fat kadaknath chicken patties.

The mean overall acceptability score differ non-significantly $(\mathrm{P}>0.05)$ between control and fiber enriched low fat kadaknath chicken patties throughout the storage. With the subsequent storage the scores were gradually decreased and showed significant $(\mathrm{P}<0.05)$ difference from $21^{\text {th }}$ day of storage.

It might be due to synergistic effect of increasing $\mathrm{pH}$ and microbial load in respective treatment during the storage. Similar observation of decreasing overall acceptability scores with increasing storage were reported by in vacuum packed guinea fowl and in vacuum packed restructured chicken chunk (11 \&15). The fiber enriched low fat kadaknath chicken patties was very well accepted to 28 day under refrigeration $\left(4 \pm 1^{\circ} \mathrm{C}\right)$.

However, thereafter sensory panelists rejected the acceptability of product. Moreover lipid oxidation product and production of ammonia from protein breakdown by microbes may lead to production of off flavor might be probable cause of poor acceptability of the product by the sensory panelists beyond 28 days. This observation indicated that microbial count and rancidity level as well as sensory attributes remained well below the permissible level and product was stable up to 28 days of storage under refrigeration $\left(4 \pm 1^{\circ} \mathrm{C}\right)$.

Application of research: It may be applicable in food industry for the development of functional meat products as well as to increase the keeping quality of kadaknath meat products.

\section{Acknowledgement}

Authors are thankful to honorable ViceChancellor NDVSU and MPCOST Bhopal for providing financial assistance for the research. * Principle Investigator or Research Guide or Chairperson of research: Dr Narendra Nayak (Major Advisor) University: NUVASU, Jabalpur.

\section{References}

A.P.H.A. (1992) American Public Health Association. 2nd edn. Will behington, DC, pp. 5-99.

Ahn, D.U., Sell, C., Jo, X., Chen, C., Wu, and Lee, J. I. (1998). Poultry Science, 77,912-920.

Anna, A. M., Venkatachalapathy, R.T., Radha, K. and Lakshmanan, V. (2014). Journal of Food Science Technology, 51(7),1370-1376. 
Anna, A.M. (2015). Shelf life of boiled restructured buffalo meat rolls in refrigerated storage under vacuum packaging condition. Journal of Applied Animal Research, 43:(3) 318-323.

Bhoyar, A.M., Pandey, N.K., Anand, S.K. and Verma, S.S. (1998). Indian Journal of Poultry Science, 32, 259-265.

Bhoyar, A.M., Pandey, N.K., Anand, S.K. and Verma, S.S. (1998). Indian Journal of Poultry Science, 32, 259-265.

Brian D.T., Maurice G., O’Sullivan R., Hamill M. and Kerry J.P. (2012) Meat Science, 91, 460- 465.

Cremer, M.L. and Chipley, J.R. (1977). Journal of Food Protection, 40, 603-607.

Deepshikha, D., Hazarika, P., Singh, T. P., Chhangte, L., Singh, P., and Talukder, S. (2016). Veterinary World, 9(6), 587-594.

Devi, R. and Singh, P. (2018). International Journal of Chemical Studies, 6(1), 840844.

Dharmaveer, S., Rajkumar, V. and Mukesh, K. P. (2007). American Journal Food Technology, 2, 238-247.

Indumathi, J., and Arun, S.P. (2017). International Journal of Science, Environment and Technology, 6, 2487 2496

Jimenez-Colmenero F. (2007) Trends in Food Science and Technology, 18, 567-578.

Kala, R.K., Kondaiah, N., Anjaneyulu, A.S.R. and Thomas, R. (2007). International Journal of Food Science and Technology, 42(7), 842-851.

Kandeepan, G., Anjaneyullu, A.S.R., Kondaiah, N. and Mendiratta, S.K. (2010). African Journal of food Science, 4(6), 410-417.

Keeton J.T. (1983) Journal of Food Science and Technology, 48, 878-881.
Koniecko E.K. (1979). Handbook for meat chemists, NJ: Avery Publishing Group Inc. New Jersey, pp. 68-69.

Kristchevsky, D. (2000). $1^{\text {st }}$ International Conference on Dietary Fibre; Dublin, Ireland; Oxford, U.K, Blackwell Science, pp 38.

Maca, J.V., Miller, R.K. and Acuff, G.R. (1997). Journal of Food Science, 62,591-596.

Malav, O.P., Sharma, B.D., Talukder, S., Kumar, R. R. and Mendiratta, S.K. (2013). International Food Research Journal, 20(1), 105-110.

Muguerza, E., Gimeno, O., Ansorena, D. and Astiasarán, I. (2004) Trends in Food Science and Technology, 15, 452-457.

Nayak, N. K. and Tanwar, V.K. (2004). Indian Journal of Poultry Science, 39(2), 142146

Nayak, N.K., Pathak, V., Singh, V.P., Goswami, M. and Bharti, S.K. (2014). Livestock Research International, 3(1), 7-13.

Snedecor G.W. and Cochran W.G. (1994) Statistical methods, $8^{\text {th }}$ Edn. The Iowa state college press, INC. American Iowa, (USA), pp 237-238.

Sudheer, K., Das, C., Mandal, P.K., Pal, U.K. and Rao, V.K. (2011). International Journal of Meat Science, 1, 62-69.

Tarladgis B.G., Watts B.M., Younathan M.T. and Dugan L.R. (1960) Journal of American Oil Chemists Society, 37, 403406.

Uikey, S., Nayak, N.K., Mehta, M.K., Chhabra, D. and Chauhan, L. (2018). International Journal of Microbiology Research, 10(10), 1382-1386.

\section{How to cite this article:}

Sunil Badole, N.K Nayak, M.K. Mehta and Ranjeet Aich. 2019. Storage Stability of Functional Kadaknath Chicken Patties under Vacuum Packaging. Int.J.Curr.Microbiol.App.Sci. 8(11): 25852593. doi: https://doi.org/10.20546/ijcmas.2019.811.299 